\title{
The political responsibility of the church: On the necessity and boundaries of the theory of the two kingdoms
}

\author{
I W C van Wyk \\ The Africa Institute for Missiology \\ Reformed Theological College \\ University of Pretoria
}

\begin{abstract}
The political responsibility of the church: On the necessity and boundaries of the theory of the two kingdoms

The voice of the church has fallen silent in the new political dispensation in South Africa. Many people in the Dutch Reformed Church in Africa (Nederduitsch Hervormde Church) argue that the church should keep its distance from politics. They are of the opinion that they could defend this position with the "Lutheran twokingdoms theory". This article shows that the theory of the two kingdoms is not a uniquely Lutheran, but also a Calvinistic interest. It furthermore shows that this theory is not only interested in separating the two kingdoms, but also in bringing these kingdoms in relationship with one another. A plea is made for loyalty to both the Lutheran and Calvinistic traditions. The article also calls for a concentration on the three new challenges in South Africa, namely democracy, pluralism and Africanisation.
\end{abstract}

\section{INTRODUCTION}

The voice of the church has fallen silent in post-apartheid South Africa. Witnesses against society and the authorities have become rare. The prophetic voice of the churches involved in the struggle against apartheid has become muted. The Afrikaans churches, which played a strong public role in the previous dispensation, have largely withdrawn from the political debate. An ecclesiastical silence prevails over political matters. The uncertainty about the socio-political role of the church in South Africa can be traced back to at least three large problematic areas, namely: a) the rise of a democratic constitutional state in which the State has adopted a neutral stance toward 
churches and religions, b) the profiling of company and religious pluralism, and c) the exercising of the power linked to the thought patterns of Africa. These three realities have caught the churches off-guard, since we were not prepared for these enormous social upheavals (cf Van Wyk 1996).

The question is, however, whether this silence is an acceptable stance for the church to take? Ought there to be a radical distance between church and politics, or could anything else be legitimately expected of the church? Many people in the Dutch Reformed Church in Africa (Nederduitsch Hervormde Church) think that the answer should be sought in a radical distance between church and politics. They are furthermore convinced that the Lutheran "theory of two kingdoms" may offer the theoretical foundation for taking this stance. ${ }^{1}$ But I am convinced that this rather sudden meddling with the theory of two kingdoms in the Hervormde Church is in numerous cases nothing more than a mechanism for ideological dissimulation. Some allege that the church and the State ought to have nothing to do with each other, so that the "new South Africa" can tranquilly complete its process of unfolding without interference from the church. Others again allege that the church and the State have nothing to do with each other, with the intention that the Church should withdraw from these foreign new realities.

The question is: Should this be so? Must the Church withdraw completely from the field of politics in the new democratic dispensation? Would the consequences not be an ascetic Christianity, escapism, religious inwardness and limiting the gospel to private life? If one has misgivings about the radical schism between church and politics, then one should surely be able to indicate why and when the church and the world could become involved with each other. This is in fact one of the cardinal issues with which Lutherans have been wrestling for the past decade (Bayer 2003:281-296;

\footnotetext{
${ }^{1}$ The explanation that can be given is that the Hervormde Church made a theological paradigm shift on the basis of changed circumstances. As the church of the South African pioneers, "Voortrekkerkerk" (Storm 1989), as State church of the Z A R (Van Wyk 1994; Pont 1969 and 1991) and as the people's church or "volkskerk" in the apartheid era (Botha 1989), the Hervormde Church had a very close bond with the people and the government. In a situation where it was difficult to distinguish among these three areas of life, it was also not strange, therefore, that a theocracy (Pont 1969, 1991) was regarded as the ideal model. However, it was not possible to persevere with theocracy - simply because circumstances had changed. As the political power and the political system of the Afrikaner came under pressure, the Hervormde Church moved away from a theocracy by encouraging an everincreasing distance between the State/politics and the Church. The policy document Church and World 2000 of 1985 and the presentation by Piet Boshoff (1995) at the ministerial preparatory course in 1995 were the highlights of this process. This process of distancing the church from politics persuaded people that the Hervormde Church, in matters of politics, was taking the path of the "Lutheran theory of two kingdoms" (Smith 1988; Buitendag 1990; Van Wyk 1991). What was true, is that the Hervormde Church did develop a feeling that it should stay out of active politics, but this feeling was far from a theological choice in favour of Lutheranism.
} 
Herrmann 2004; Pannenberg 2004a). Many Lutherans claim that their "theory of two kingdoms" was not appropriate for preventing the inhumanity of World War II and unable to handle the problems of a plural society (Westhelle 2005; Henriksen 2005). Before we wish to claim categorically that the theory of two kingdoms could be the ideal means for us in South Africa to handle our contemporary problematic, we first have to examine the discussions in the past concerning the "theory of two kingdoms". ${ }^{2}$ There we will find instructions on whether this theory may help us to gain a perspective in these confusing times.

\section{EARLY CHRISTIAN AND ROMAN PERSPECTIVES}

Throughout the history of Christianity there has been a constantly changing shift in the distance and rapprochement between the church and the world. The predominant impression one gains from the New Testament, is that the church has nothing to do with politics and politics has nothing to do with the church (2 Th 3:2). In the time of the greatest prosperity of the Roman Empire, Jesus preached that the kingdom [of God] was at hand (Mk 1:15). To Pilate He said that this kingdom did not belong to this world (Jn 18:36). The assembly of the faithful is therefore in heaven (Phlp 3:20) and they know that they have no permanent home here on earth (Heb 13:14). The faithful look forward to a new heaven and a new earth where there will be true justice (2 Pt 3:13). It is clear in the New Testament that a faithful person should never identify himself too closely with the State and politics. There ought always to be a clear distinction between the church and the State since the church should always be a different kind of community - a community in which there are other kinds of relationships (Mt 20:25-28). This good institution of God may also easily degenerate into a demonic power ( $R v 13$ ), and therefore a believer ought always to keep a distance from this institution, since he should always be more obedient to God than to a man-made authority (Ac 5:29).

In pre-Constantine Christianity when there was not yet a theory about the relationship between the church and the State, one can speak of a "practically lived theory of two kingdoms". In practice the Christians distanced themselves from the political sphere. They did not occupy government positions and refused to perform military service. The reason was probably

\footnotetext{
${ }^{2}$ This undertaking is not as simple as theologians of our Church may think. As shown in point 4 , the "theory of two kingdoms" is indeed a Lutheran achievement, which does not necessarily go back in all respects to Luther himself. Furthermore there have already been frequent references to the "Irrgarten der Zwei-Reiche-Lehre" (Heckel). Sauter speaks of an "unentwirrbaren Problemknäuel" and Wolf calls this "theory" an "Art Geheimwissenschaft" (cited in Kern 1986:237). In other words, we are not dealing here with a clearly developed dogma, but with a jumble of frequently unfounded and contradictory opinions and meanings.
} 


\section{The political responsibility of the church}

that Christians, who would have occupied government positions, would also have been obliged to take part in the deeds of the political cult. In addition to these reasons of circumstance, there were also reasons of principle for their attitude to life. These reasons are stated well in the epistle to Diognetus V, 1VI, 3:

For the distinction between Christians and other men, is neither in country nor language nor customs. For they do not dwell in cities in some place of their own, nor do they use any strange variety of dialect, nor nor practise an extraordinary kind of life ... Yet while living in Greek and barbarian cities, according as each obtained his lot, and following the local customs, both in clothing and food and in the rest of life, they show forth the wonderful and confessedly strange character of the constitution of their own citizenship. They dwell in their own fatherlands, but as if sojourners in them; they share all things as citizens, and suffer all things as strangers. Every foreign country is their fatherland, and every fatherland is a foreign country. They marry as all men, they bear children, but they do not expose their offspring. ${ }^{3}$ They offer free hospitality, but guard their purity. Their lot is cast "in the flesh", but they do not live "after the flesh". They past their time upon the earth, but they have their citizenship in heaven. They obey the appointed laws, and they surpass the laws in their own lives. They love all men and are persecuted by all men ... They are warred upon by the Jews as foreigners and are persecuted by the Greeks, and those who hate them cannot state the cause of their enmity ...Christians dwell in the world, but are not of the world.

(Goold 1976:359-363)

In spite of the Biblical and early Christian statements which gave rise to a theory of two kingdoms in which the church and the world are radically distinguished from each other, it would be wrong to hold the view that the church and the world, kingdom and politics have to be radically separated in all respects. The information in the New Testament simply does not allow it. Different Biblical writers point out that God has willed the rule of law and the rule of the State. The State is an institution of God. It receives its authority from God; and for this reason the church cannot and may not withdraw completely from the State. Indeed, it is not possible for the church to do so, since it has to pray constantly for the authorities so that they can rule according to the will of God ( $\operatorname{Rm} 13: 1 ; 1 \mathrm{Tm} 2: 1-3)$.

\footnotetext{
${ }^{3}$ Some translators make a case from this statement that this practice could also include abortion.
} 
The trends of distancing and approaching which we encounter in the New Testament and the earliest Christianity persist throughout the history of Christianity. Sometimes there is a greater emphasis on distancing and at other times a greater emphasis on approaching. This interaction in emphasis has been brought about not only by a change in theoretical considerations, but also and perhaps more particularly by the change in political circumstances. Augustine ${ }^{4}$ was the first theologian who submitted a comprehensive and influential theory about the relationship between the church and the State. His theory on the two cities can be regarded as the precursor to the later theory of the two kingdoms. In his late magnum opus, De civitate Dei (413-426) he takes the stance that one should concentrate more on a distinction between civitas Dei and civitas terrena. With this distinction, Augustine did not intend to say that the church and the world have nothing to do with each other, but that God instituted two ways of ruling for governing over his creatures. The one is a spiritual way of ruling as represented by the church and in particular its office(s), and the other is a worldly way of ruling as represented by the worldly authorities and in particular the emperor.

Augustine's theory of two cities led in the Middle Ages to the development of what is called the two-swords theory. The primary aim of this theory was to verbalise the ideal defining the two cities or two kingdoms within the body of Christ, called the corpus Christianum. This theory proposes that the worldly government should be subject to the spiritual government. The emperor should therefore be subject to the pope because the church was entitled to universal rulership. The reason for defining this relationship between the church and the government goes back to the vision of reality that prevailed in mediaeval Christianity. This reality was not only postulated as a unit but was also accepted as such. No independence was accorded to the State, since the State was viewed as only a way of governing within God's reality. The conflicts between emperor and pope occurring at that time were therefore never conflicts about sole sovereignty, but about who should take leadership in the one kingdom (Zimmerman 1987:401). Therefore the twoswords theory has to be seen against the background of the "theory of one kingdom" of the Roman Catholicism of that time (cf Küng 1994:336-601 for completeness).

What is important to us in this theory and teaching, is the fact that the State, the authorities and politics were not seen as independent, autonomous legal entities. Politics had a religious dimension for theologians in the Middle Ages. They believed politics could not be practised independently of ethics

\footnotetext{
${ }^{4}$ As in a previous article (Van Wyk 1991:731-732) I made an excursion into Augustine's view of the State, I shall not go into his theology again here. For an outstanding interpretation and exposition of Augustine's political science, reference can be made to Ruokanen (1988:22-41).
} 
and higher ideals. For this reason, politics in the Middle Ages was not subject to the dictates of nature but under the guidance of the Spirit, and this was the reason for the opinion that the worldly had to be subject to the spiritual (Zimmerman 1987:399).

\section{REFORMATORY PERSPECTIVES}

\subsection{Historical necessities}

The Reformation period is characterised largely by the distinction between the church and the political state. The unitary thinking of the Middle Ages was not extended during the Reformation. At least three factors contributed to this stance. In the first place, reference can be made to the epochal changes occurring in Europe, which contributed to the demise of the church-state relationship that had been decided in the Middle Ages. The authorities systematically emancipated themselves from the church in the decades before the dawn of the Reformation. The emperor no longer allowed the pope to prescribe to him in everything. Accordingly, a distance grew between the two styles of ruling, since the authorities held the view that they had a right to autonomy. The Reformers had to take these realities into account. Their theoretical consideration would therefore give clear signals of an acceptance and positive utilisation of their historical realities. The fact that the Reformers placed an exceptionally strong emphasis on the distinction and distance between the church and the State was therefore also due to the change in the relations of real power.

The Reformers did not all blithely accept the emancipation of the State as an irrevocable fact, but also valued the rise of two autonomous spheres of life as a development in the right direction (Joest 1986:603). The second reason which may be advanced for the Reformers' plea that a distance should be kept between the church and the State, was the detrimental consequences that clerical political interference had for the church. Within the corpus Christianum, the bishops were involved in a struggle for political power and eventually also became caught up in the violence exerted by the State, with extremely negative consequences for the church. The Reformers knew about this, and from their sense of responsibility to the church, argued that the church had to emancipate itself from the daily struggle for political power. For this reason, the Reformers not only promoted the emancipation of the State, but also that of the church itself. In their opinion, the emancipation of the church had to take place concurrently with the emancipation of the State. The Reformers' position was that the church and its proclamation of the Word should not have anything to do with violence. The kingdom of God is a 
kingdom where there is no violence, whereas the kingdom of the world is a kingdom of violence. Calvin in particular saw the church as a place where people should live and work in freedom, without coercion.

The Reformers also put forward another argument in this regard. They realised that when a bond of unity arose between the church and the State, the church could easily become degraded into a mere appendage of the State, and would in this way become redundant. This therefore concerns the discovery that the church has to be the light of the world, and that the church should not abandon her identity through conformism. The church (as assembly of the faithful) has to preserve her identity by following the Word in obedience. The implication is that the church is not meant to echo the authorities; may not be the sanctioner of the State's power, but should stand on her own feet and be wholly the church. The State should also be wholly the State, and not try to be a quasi-church. This is the excellent commonsense of the theory of two kingdoms, which all the Reformers endorsed (Busch 1992:160-163). The third reason for what can be called the distance thinking in the Reformation, concerned the political turpitude of the Roman Catholic Church. Roman Catholic theologians sowed seeds of suspicion that Protestantism was not only a rebellion against the Roman Catholic Church, but also a planned revolt against the (Roman) emperor. This was why the Reformers came up with the slogan: "We proclaim only the pure Word of God, because we do not want to foment any rebellion against the authorities" (Busch 1992:161). The strong insistence on obedience to the authorities should also be understood against this background. One would therefore have to say that the design of the Reformation theory of two kingdoms also concerned an element of anti-Roman polemics.

\subsection{The standpoints of Luther and Calvin}

Luther and Calvin agreed theologically with each other that the church and the world, faith and politics should be separated from one another. They were therefore also in agreement that one would have to work with some or other form of the "theory of two kingdoms". But they based this requisite distinction on different perspectives. Luther (and Zwingli 1981) argues from the concept of "justice", and Calvin from the concept of "freedom", the need for the distinction between the two kingdoms. Luther and Calvin also concurred that these two kingdoms could not and should not be radically separated from each other. Both realised that there would have to be reciprocal dependence and influence between them. The opinion that there is an unbridgeable gulf between the "Lutheran theory of two kingdoms" and the "Calvinistic theory of the sovereignty of Christ" (Moltmann 1984) is in my opinion rather far-fetched. 


\section{The political responsibility of the church}

I doubt whether Luther and Calvin would have said things so differently had they lived in the same socio-political conditions. The fact that Luther had to deal with principalities (some of which were Protestant, others Roman Catholic and yet others heathen) in the initial years of the Reformation, and by contrast Calvin had to deal with city-states (with governments which were regarded as Calvinistic), would necessarily have highlighted differences in emphasis. Understanding should be shown for this, and it is still no reason for forcibly separating Lutherans and Calvinists into two irreconcilable camps.

\subsubsection{Luther}

Luther's (1991a; 1991d:58) argument is that there are two types of righteousness for the Christian. The first type of righteousness is a foreign righteousness from an external source. This is the righteousness which is given freely to us purely through merciful compassion. This righteousness, which is sometimes called the righteousness of Christ and sometimes the righteousness of God, is made through faith to our righteousness. No human work can contribute to this foreign righteousness. It is entirely a matter of the Triune God. The second type of righteousness concerns our own deeds. It deals with the combating of desires, the love for neighbours and humility before God (Luther 1991a:370). This righteousness is the fruit and result of the first kind of righteousness. Furthermore it completes the first kind of righteousness, since it contributes to the destruction of the old Adam (1991a:371).

The good work of loving one's neighbour should, Luther claims, also be expressed in the political sphere. For Luther, this sphere is the institutions of the authorities (Luther 1991d:53). Inside these institutions, work should be done to create and preserve outer peace, through which society could be protected against the sins of the believers as well as those of unbelievers, which encroach upon community life (peccatum criminale WA 2, 43, 6). The implication is that Christians, who do not need authorities, should also engage in doing this good work. As a small minority group, they are part of the world this world which is the good creation of God (Luther 1991c:16, 23), and therefore they have to contribute through their good works to the well-being of society by being subservient within State institutions (Luther 1991c:10-28; 1991d:58). Good works of a political nature are always aimed at promoting the welfare of the whole.

For this reason, Luther cannot approve of using the gospel for promoting group interests, for example the interests of the farmers (Schwarzwäller 1980:98-99). The good works that have to be performed in the field of politics are only part of the second kind of righteousness. It is and 
remains mere earthly righteousness which makes no contribution to the salvation of humankind. In the same way, Luther advocates obedience to the authorities. His view is that subjects must obey the authorities. This obedience of citizens is also an excellent virtue. It amounts to civil justice. Whoever subjects himself to the rule of law, Luther claims, will receive the necessary reward on earth and a lesser punishment at the last judgement, but this will not make salvation possible for mankind. For Luther, obedience to the authorities amounts to "external justice". However, this "external justice" cannot save mankind from essential sin: the original sin existing since birth, the sin that comes from outside us (peccatum essentiale, natale, originale alienum WA 2, 44, 14). For this salvation, God himself in and through his Son had to establish the actual external justice; the iustitia natalis, essentialis, originalis, aliena ... Christi (WA 2, 44, 32). It is only this external justice that will save us at the last judgement. Based on the above arguments, Luther holds the view that one should distinguish between two regimens or kingdoms. Luther (1991c:15) says: "Deshalb hat Gott zwei Regimente verordnet: das geistliche, welches durch den heiligen Geist Christian und fromme Leute macht, unter Christus, und das weltliche, welches den Unchristen und Bösen wehrt, daß sie gegen ihren Willen äußerlich Friede halten und still sein müssen."

What should be emphasised is that Luther did not work with the idea that the church and the believers had to withdraw from government, politics and public life. Luther (1991c:23) says Christians live in this good (not evil) world with its institutions. They are supposed to pursue earthly justice. They do so when they serve their fellow men by fulfilling their official duties in the civil service (Luther 1991c:19; 1991d:52). These official duties even include the work of an executioner. According to Luther, the argument cannot be made that such an office is in conflict with the prescriptions of the Sermon on the Mount, since one should distinguish between an office-bearer and a private person. As a private person the Christian should strive to follow the prescriptions of the Sermon on the Mount, but this does not mean that a Christian may not perform the official duties of an executioner. A Christian may be an executioner, since through this he also gives effect to the commandment to love. This governmental task to punish - and even to punish with death - serves the commandment to love. It contributes to the protection of one's fellow men, and so to the promotion of peace on earth (Luther 1991a:376-378; 1991c:19-23). The implication of this argument is not that an official personality does not need to do his work according to the dictates of the Word. From Luther's sermons it is clear that he is indeed convinced that officials and politicians could and should work according to the dictates of the 
gospel. Reference can be made, for example, to his "Weimarer Predigt" of 2510-1522, stating the following:

\begin{abstract}
Also soll auch ein jeglicher Christ seine Werke dahin richten, daß sie im Geist Gottes gehen und daß er dem Nächsten auch damit diene. Also soll der Fürst gedenken: Christus hat mir gedient und alle Ding zu einer Nachfolgung getan, also will ich auch meinem Nächsten dienen, ihn beschützen und handhaben bei dem Seinen, und darum hat mir Gott das Amt gegeben und hab auch das darum, daß ich inm dienen soll. Das wäre ein Fürst und guter Regent. Wenn ein Fürst also sieht seinen Nächsten unterdrücken, so soll er gedenken: das geht mich an, ich muß denn meinen Nächsten schützen und schirmen. Wo das nicht im Fürsten ist, so steht sein Regiment nimmermehr wohl. Er muß regieren im Reich Gottes. Also soll auch tun ein Schuster, Schneider, Schreiber oder Leser: Ist er ein christlicher Schneider, so sagt er: Den Rock mache ich darum, daß mirs Gott geboten hat und daß ich etwas verdiene, damit ich meinem Nächsten helfen und dienen kann. Wo nun ein Christ dem andern nicht dienet, da wohnt Gott nicht, da ist auch nicht christlich Leben.
\end{abstract}

(WA 10, III, 382, 2-16, according to the version by Seils 1993:100-101)

The implication of the previous argument is that authorities can and should govern according to the guidelines of the Word ${ }^{5}$ (Luther 1991d:68, 72). After all, Luther's wish was that the kings and princes should be good and faithful Christians. They should also hold dear to their hearts the well-being of their subjects. Therefore in their task of governing they should also give expression to the commandment to love (Luther 1991c:24, 41). In numerous cases, however, the authorities ought to make decisions and rulings according to human reason (Luther 1991c:41; 1991d:73). However, to Luther "human reason" does not mean ordinary human wisdom. It implies that a government should not make foolish decisions which would endanger people's lives. For example a war should not be waged if the war cannot be won (Luther 1991c:47). But this does not mean that the gospel could not and should not be the yardstick for a worldly government.

I have found in Luther no confirmation that he would have said that the authorities fall beyond the sovereignty of God and could therefore do as they pleased according to their own rules of law. Instead, the contrary is true. Luther indicated clearly that the authorities are institutions of God and are

\footnotetext{
${ }^{5}$ Often (for example in Ruokanen 1988) one reads precisely this argument that Luther saw no positive association between the Word and politics.
} 
consequently under his sovereign rule. To confirm this standpoint, reference may be made to his sermon on 24 October 1522 in the "Weimarer

Schloßkirche" where he asserts the following about the sovereignty of Christ:

\begin{abstract}
Nun wöllen wir das geistlich und weltlich Reich Christi von einander scheiden. Das weltlich Reich hat Christus in den Kindern von Israel von Mose an bis auf Jesum gebraucht, da er innen Gesetze gab, als in Kleidung, Essen, Trinken, Zeremonien und andern Dingen. Aber da Christus ist Mensch geworden, hat er das geistlich angenommen und das weltlich fallen lassen, nicht daß er kein Herr mehr darüber will sein, sondern daß er Fürsten, Kaiser und Amtleut darüber etwas zu tun, mit dem armen Volk auch getreulich umzugehen gesetzt hat, und er will gleich wohl das regieren und ein Herr darüber sein.
\end{abstract}

(WA 10, III, 371, 19-26, according to the version by Seils 1993:103)

Luther not only expects the authorities to rule in accordance with demands of the Word, but also and in particular to protect Christianity. All authorities (including non-believer princes) should therefore, Luther insists, preserve and promote the Christian religion as the true religion. The authorities should give their support to the church, especially against external threats, such as the dangers that the Turks posed (Luther 1991e:103). The implication of this standpoint is once again that the church has the right and the responsibility to prescribe to the authorities and figures in authority calling themselves Christians, how they should govern (Luther 1991e:106; Wendebourg 1992:205-207). Luther (1991b; 1991c:9) sent complete "pastoral letters" to the Christian princes. He did not intend to submit better laws to them, but to make their consciences keener so that they would have a change of heart. When princes made the laws, love should also be the decisive factor. The subservient Christ always had to be kept in view (Luther 1991c:42-43). The converse argument does not apply, however. According to Luther the authorities did not have the right and privilege of dictating to the church. Luther insisted strongly on the autonomy of the church. Faith is the work of the Word and the Spirit. Faith cannot be ordered and forced. For this reason the authorities may not prescribe what people should believe (Luther 1991c:29-32). Therefore they could not help the church to support the true teachings. Only the church should combat heretics. Heresy could not be combated with violence. It should be mentioned here, however, that Luther did not stick consistently to this principle (Luther 1991c:37). Later in his life he nevertheless made use of the State's power to help combat heresy (Wenz 
1995:146). Furthermore, Luther also opposed the clericalisation of politics. He claimed that ministers (or bishops) should be solely engaged in proclaiming the Word. Unlike worldly princes, they might not rule with laws (Luther 1991c:32).

\subsubsection{Calvin}

Calvin ([1821-1859] $1991=$ Inst IV, 20) deals in the last chapter of his Institutio Christianae Religionis of 1559 with the political regime or sphere under the heading de politica administratio. Right at the beginning of the chapter $(1991: 1821=$ Inst IV 20,1$)$ he reminds the readers that the theory of two kingdoms, as he describes it in Inst III,19,15, is his point of departure when he discusses politics (cf Staedtke 1972 and Zimmermann 1993 for completeness). Calvin $(1991: 1074=$ Inst III, 19, 15) treats the theory of two kingdoms as the theological point of departure in a chapter dealing with freedom and, more specifically, with freedom of conscience. He states that there is a twofold governance in man: The one is a spiritual governance which trains his conscience to be the fruit of God, and the other is a civil governance which educates man to comply with his citizenship.

Calvin speaks in this respect of the spiritual jurisdiction and the temporary jurisdiction, of the spiritual kingdom and the civil kingdom respectively. Calvin claims that by using this distinction, people will not make the mistake of wrongly imputing to the civil order that which the gospel teaches in relation to spiritual freedom. Therefore, a believer can live with this freedom of conscience that that which could not be achieved politically and that which has not yet been achieved politically, does not determine redemption or rejection. Calvin's point is therefore: the certainty of salvation is free, as opposed to political and societal failures. Calvin furthermore makes the deeply insightful statement that freedom of conscience is more important than the adiafora (moral matters of moderate importance). He adds that the petty civil moral disputes do not affect the debate about salvation and damnation (Zimmermann 1993:36). In view of the fact that in their reflections about the relationship between the church and the State, Luther and Calvin had the theory of two kingdoms as their common point of departure, it is really surprising that in the research (Staedtke 1972:202-203) the opinion is that such vast differences can be detected between the two. There are certainly differences, yet I wish to defend the thesis that in this matter the only differences between the two are differences in emphasis and nuance. For this reason I believe it suffices to point out these differences in emphasis in this article. 
The theory of two kingdoms never had for Luther and Calvin the implication that the church and the world, religion and politics should be radically separated from one another. Where Luther based this tie of unity on the creative work of God, Calvin by contrast based it on the acts of God. Calvin pointed out that God is not absent outside the boundaries of the church. He is also Lord in the world, in politics. In his commentary on Daniel (Busch 1992:164), Calvin states: "Wenn Gott auf the Alleinherrschaft in der Welt verzichtet, so daß alles blind und sinnlos verläuft, so hat er aufgehört, Gott zu sein." Luther also said this, but Calvin merely gave it a different emphasis. Luther emphasises that God is present in politics in a different way from His presence in the church. By contrast, Calvin emphasised that the same God who is present in the church, is also present in politics.

This difference in emphasis led Calvin to speak more clearly of Christ as the Lord and King of the world (Busch 1992:164). On this basis he could involve the church and the world more closely and easily than Luther. Since Christ is also the Lord of politics and the authorities, it is difficult for Calvin to conceive of God independently of these earthly realities (Inst IV, 20, 2, 1-3). It is therefore understandable that Calvin could say that the statement "that faith has nothing to do with politics, is a statement of the devil" (Busch 1992:163). Therefore Calvin necessarily sees a very intense co-operation agreement between the church and the State. Calvin's view is that the authorities also have a responsibility towards the church. He believes that the authorities ought to create favourable conditions conducive to Christian preaching. The worldly kingdom, according to Calvin, has a responsibility for promoting the spiritual kingdom. Calvin (Inst IV, 20, 2, 19-24) states:

\footnotetext{
But as long as we are among people, this government is destined to cherish and protect the external religion; to protect the healthy teaching of the fruit of God and the state of the church; to adjust our lives to the community of people; to form our morals according to civil justice; to reconcile ourselves with one another and to nurture our common peace and repose.
}

Calvin never intended that the State should interfere with ecclesiastical matters such as preaching, but that it would devote itself zealously to the work and welfare of the church. In this respect, Calvin judged that the State not only had a responsibility toward the second table of law, but also toward the first table. Although Luther also says this, Calvin says it more loudly and clearly. He warns more intensely against paganism and secularisation. Therefore it should not be a surprise to hear that Calvin entrusted far more to the 


\section{The political responsibility of the church}

authorities than Luther was prepared to. Pursuant to Rom 13, Calvin (Inst IV, $20,4,1-10)$ regards the authority, just like Luther, as an institution of God.

However, Calvin believed that the task of this God-willed institution was broader than it was in Luther's opinion. Calvin judged that the task of the authority was not only restricted to the maintenance of law and order, but that it should also strive to promote law and justice. Calvin stated that an authority could not do this unless it had knowledge and understanding of the Word of God. He believed that the Word was the only yardstick for the realisation of a just political order (Inst IV, 20, 9). The justice to be pursued had the commandment to love as its foundation. For this reason, the authorities ought to listen closely to the teaching of the church when it interpreted the commandment to love (Inst IV, 20, 14-16). The church's task was therefore to influence legislation, in other words to contribute to the development of the law. Calvin was therefore in favour of "constitutionality". He knew that law and justice were not achieved through power and violence, but through legislation (Inst IV, 20, 9-13). But in Calvin's opinion, law could not be genuine law unless it had a religious basis. The administration of justice "as if God does not exist" (Hugo Grotius) was foolishness to him. For this he invoked the heathen philosophers (Inst IV, 20, 9, 1-6). What was expected of a government was that in its legislation it should come as close as possible to the will of God. Laws had to conform to the will of God. To Calvin this meant that the laws had to comply with the requirements of the commandment of love (Inst IV, 20, 15).

This did not mean that there would ever be total identification between laws and the will of God, but it should not prevent the continuing search for an analogy. An analogy would be achieved when a State could ensure a decent society for everyone. This would be achieved when law (iudicum = suppression of the stronger), justice (iustitia = protection and liberation of the innocent) and peace (communis omnium salus = general satisfaction) prevailed (Inst IV, 20, 9). The difference in emphasis on the concept of the State also gives rise to a difference of opinion in matters of obedience to the authorities (cf Van Wyk 1995 for completeness). Luther tends toward the thesis: "Die Obrigkeit ist Gottes Dienerin, weil und sofern sie Obrigkeit ist." By contrast, Calvin tends towards the thesis: "Die Obrigkeit ist zu achten, weil und sofern sie Gottes Dienerin ist" (Busch 1992:166). That one owed greater obedience to God than to other people/authorities was therefore to Calvin not only an ultima ratio in extreme cases of conflict, but also a basic axiom of faith. The authorities, according to Calvin, merited only relative obedience, not absolute obedience. 


\section{ALIENATION BETWEEN LUTHERANS AND CALVINISTS}

In principle and historically it is necessary for all "Reformatory" churches to orient themselves to some or other form of the "theory of two kingdoms". The theory of two kingdoms is clearly not solely a Lutheran matter, as is frequently and erroneously thought, but is in fact an ecumenical matter. In other words, it is also a Calvinistic interest (Staedtke 1972; Zimmerman 1987 and 1993). The theory of two kingdoms is a dogma of ecumenical interest since it addresses an "allgemein christlich-theologisches Problem" (Honecker 1981:129). It has ecumenical support since it puts into words the basic intentions of the gospel.

The theory of two kingdoms is a characteristic of the Judaeo-Christian tradition (Lohse 1983:191). It has even been described as follows: "Die Vorstellung von zwei Reichen und Regimenten ist einer der grossen Entwürfe der Menschheitsgeschichte, mit der gesamten menschlichen Wirklichkeitserfahrung theologisch fertig zu werden" (Duchrow 1977:273). The theory of two kingdoms can therefore justifiably be called the theologumenon of the Christian's attitude to the world. Its ecumenical attractiveness lies on the one hand in the success of conceiving of the Christian's involvement in the world from the distinction between the kingdom and the world (Ebeling 1972:332), and on the other hand by involving the kingdom and the world with each other in a responsible manner (Tödt 1980:91 and Reuter 1983:172 speak of the "Zuordnungsfunktion").

Unfortunately this perspective gave rise to serious differences of opinion in the years around World War II. In these years, leading Lutheran theologians remodelled Luther's theology into a theory of two kingdoms in which the two kingdoms had nothing to do with each other. The consequences, as everyone knows, were catastrophic. Two main perspectives contributed to this radical separation of the church from the world. The first perspective concerned the essence of the worldly kingdom, and the second the interpretation of the relationship between the law and the gospel. In these years there were Lutherans who argued that there were two kingdoms that were in permanent conflict with each other. From the numerous writings of the lawyer J Heckel (cf Schrey 1969:517-556 for an overview) it seems that certain Lutherans perverted the "Lutheran theory of two kingdoms" by arguing that within mankind there were two corpora, the corpus Christi mysticum (the church) and the corpus Babylonicum (the people of the devil), which were engaged in an interminable campaign against each other. In this argument the "Reich zur Linken" (the State) is eventually identified with the regnum diaboli, implying that it was not under the sovereignty of Christ. The belief that the world was God's good creation disappears here. In this pattern of thought, the apocalyptic dominates whereas Christology becomes diluted. 


\section{The political responsibility of the church}

Furthermore, it is so that the idea of the simul iustus et peccator is lost from sight. That this interpretation of Luther is untenable, is generally acknowledged by Lutherans (Honecker 1981:131).

In the time of National Socialism, Lutherans loyal to the party interpreted the relationship between the law and the gospel, which largely contributed to the church's reluctance and incapacity to warn against evil tendencies in politics. In 1934 Paul Althaus and Werner Elert from Erlangen compiled a document for the Ansbacher Ratschlag about the relationship between the law and the gospel. Based on this document, the National Socialists could legitimise their political goals. Althaus and Elert adopted the Lutheran (and Calvinistic) standpoint that the law in its primary use (usus primus) or then its political use (usus politicus/civilis), was recognisable. The (2nd table of the) law is the summary of natural law and this is why all people are answerable under the law. The law of God therefore applies to all people. Althaus and Elert explained this general validity of the law by means of the category "revelation of creation". This revelation of creation was to them something that preceded the revelation of salvation. All people, irrespective of their faith or lack of it, could share in God's will. They believed the will of God was recognisable not only in the church's preaching of the law, but also in the national laws of a State. However, the national laws emanated from the will of the people, which was in reality only the will of the party, and for that reason they equated the will of God with the will of the people/party. That was why National Socialism was to them the "Deutsche Stunde der Kirche" and the whole movement was seen as a piece of gratia historica. This argument therefore made it possible to legitimise theologically the rise of National Socialism (Honecker 1990:70-82; Nowak 1981).

The consequence of the arguments that on the one hand, the church and the State had nothing to do with each other, but that on the other hand the church had to give religious status to the State's laws, was that in Lutheranism people worked with the idea that the State could be left to its own legitimate devices, since God's general mercy also prevailed there. Since to them the State was not the terrain of the church, they believed the church should be engaged solely with the salvation of the souls of its members, and politics should be left to the politicians. Politics was to them a matter of reason (Schwarzwäller 1980:92) and not of the will of God (Joest 1986:604). In this way, religion became restricted to the private life of the individual.

Many influential Calvinists, such as Karl Barth, could not reconcile themselves to these developments in Lutheranism. In particular, they could not accept that the church was not allowed to have any say in politics and especially the evils in politics. It is not surprising that it was in fact the 
Calvinists who objected to these developments. When the history of the origins of the two confessional groups are called to mind, it is understandable that large differences of opinion emerged concerning the relationship between the church and politics. The following may be briefly recalled:

- The Lutheran Reformation began in principalities and monarchies, whereas the Gereformeerde/Hervormde Reformation originated in the cantons or city-states of Zurich, Geneva and Strasburg. These cantons already knew a form of democracy, thanks to the magistrate system. From the outset, therefore, every Reformer was a responsible citizen. This was why right from the start, reformed faith and political responsibility were more closely linked to each other among citizens of cantons than among the subjects in the princedoms.

- The basic idea of the Reformed civitas Christiana is that faith and politics could not be separated from each other. In the church and the State, people had to ask continuously about the will of God. It was not only Calvin but also Zwingli who thought about matters in this way. In the disputation of Zurich in 1523, Zwingli (cited by Moltmann 1984:138) states: "Die Obrigkeit hat Kraft und Befestigung aus der Lehr und Tat Christi" (proposition 35). "Man ist inr Gehorsam schuldig, sofern sie nichts gebietet, das gegen Gott ist" (proposition 38). "So sie aber untreulich und außer der Schnur Christi ( $\mathrm{d}$ h der Bergpredigt) fahren würde, möge sie mit Gott abgesetzt werden” (proposition 42).

- Zwingli and Calvin never had any idea of building the kingdom of God on earth. Both of them worked with a theory of two kingdoms in which human and divine justice were radically separated. However, they did take the stance that Christ should be emulated in politics too. What they did not do, therefore, was to take the law and the gospel radically asunder. They did not speak of the law here, and then speak of the gospel there, but asked about the correspondence (Entsprechung) between human justice and divine justice. In this way they shaped the law in the form of the gospel.

- Luther postulated the contrast between the clericalism of the Middle Ages and the "general priesthood of the faithful" and through this, discovered the rights of the congregation. The Reformed tradition discovered the "general kingship of the faithful" (Moltmann 1984:138) and with this, laid the cornerstone of democracy. Luther fought against 
clerical tyranny, whereas Zwingli and Calvin fought against political tyranny and by doing so, paved the way for constitutionality. Then it was possible for someone like John Milton (cited by Moltmann 1984:138) from the ranks of the Calvinists to say: "Die Krone sitzt auf der Verfassung der freien Bürger" and not on the head of the king.

In times of sharp differences of opinion, theologians like to invoke their own tradition, since support from a tradition gives a theologian legitimacy. In the sombre years surrounding World War II the Lutheran and Calvinistic traditions were in fact invoked by all quarters. At all costs it had to be proved that a particular ecclesiastic-political vision led back to either Luther or Calvin. By invoking the theologies of Luther and Calvin, the "Lutheran theory of two kingdoms" and the "Calvinistic theory of the sovereignty of Christ" arose. In the research (Schütte 1978; Kern 1986:237; Nowak 1981; Schwarzwäller 1980:91; Pawlas 1990) there is unanimity that the term "theory of two kingdoms" is a very recent term. There is a suspicion that the term might have been coined in the 1920s. Concerning the accusation that the Lutherans left the State (and more specifically the Nazi State) to its own devices, Karl Barth was probably the first to use this specific expression to Paul Althaus. After that the term was used by E Hirsch in 1934 and then by H Diem in 1938. In fact it was Diem who insisted that the "theory of two kingdoms" had to be associated with the theology of Luther. From then on, and only from then on, the conflict about the "theory of two kingdoms" was conducted as a conflict around Luther's theology. From these years onward, theologians used the terms "theory of two kingdoms" and the theory of the "sovereignty of Christ" as a way of expressing a legitimate and an illegitimate political conviction.

Historically the concept of the "theory of two kingdoms" was used by the conservative Lutheran Nazis and the "sovereignty of Christ theory" by the resistance movement in the Confessing Church. It is important to note that the term "theory of two kingdoms" is a change from Luther's term "theory of regiments". This change in the name and type of this particular theory or case indicates the programmatic shift in theology during and after World War II. The "theology of arrangements" was replaced by a "theology of acting". The "theory of two kingdoms" is therefore an act-specific category. Certain theologians use this theory in an attempt to prescribe how people should act socially and ethically (Schütte 1978:343). By contrast, Calvinist theologians during and after World War II felt that the "theory of two kingdoms" was not a satisfactory theory for acts. The view was that the eschatological category, 
"sovereignty of Christ" would better enable Christians to fulfil their political responsibility. At this point a brief glance could be taken at the attempt of the influential Calvinist Karl Barth to propose how the church and politics could be involved in a responsible way with each other.

Barth was not fated to leave a complete dogma on the State in his Kirchliche Dogmatik. He had in fact planned to give political science its dogmatic place in the fifth band, under the heading, "ethics of eschatology". Because of this lack, we have to rely on a few texts by Barth (cf Jüngel 1986 and De Kruijf 1994 for a full overview). The problem is that one has a superficial impression that Barth had either contradicted himself or changed his standpoint over the years. Friedrich Graf (1990:735) points out, however, that Barth's theology should be understood as "kirchliche Milieutheologie". By this he means that Barth's theology has to be understood as reactions to different challenges in the course of history. For this reason it is explicable and understandable that Barth emphasised different perspectives in the different stages of his life. The political circumstances and events before, during and after World War II therefore largely determined the content of Barth's theology.

Karl Barth remained true to his own "Reformatory" tradition as a Calvinist. For this reason, the theory of two kingdoms played a crucial role in all $^{7}$ his reflections on the relationship between the church and politics (Greive 1987:102; Kern 1986:245-255). In the 5th thesis of the Barmen Theological Declaration (1934) he assigned a special function to the theory of two kingdoms. There Barth formulated it as follows:

\begin{abstract}
Wir verwerfen the falsche Lehre, als solle und könne der Staat über seinen besonderen Auftrag hinaus the einzige und totale Ordnung menschlichen Lebens werden und also auch the Bestimmung der Kirche erfüllen. Wir verwerfen the falsche Lehre, als solle und könne sich the Kirche über ihren besonderen Auftrag hinaus staatliche Art, staatliche Aufgaben und staatliche Würde aneignen und damit selbst zu einem Organ des Staates werden.
\end{abstract}

In the years when the totalitarian State was a threat, Barth therefore reached back to the theory of two kingdoms - but then in its true "Reformatory" meaning, not in the meaning the Nazis had ascribed to it (Pawlas 1990:326329). In a confessing way he gives dogmatic quality to the theory of two

\footnotetext{
${ }^{6}$ For full overviews about the theory of the sovereignty of Christ, see Walther (1990); Schütte (1978); Moltmann (1984).

${ }^{7}$ Barth, up to and including his last important political document, Christengemeinde und Bürgergemeinde (1946) remained true to the "theory of two kingdoms" (De Kruijf 1994:32-38).
} 


\section{The political responsibility of the church}

kingdoms. In this way, he could combat the false theory about the State. On many occasions Barth defended (ethics lectures of 1928/29 and

Rechtfertigung und Recht of 1938) this step in order to make political science a confessional matter, since he said it would be in line with the "Reformatory" tradition (Jüngel 1986:93). Barth's primary intention was to place limits on the function of the State. By restricting its function to law and peace, he could prevent the State from becoming elevated to an institution for salvation. Limiting the State to service would preclude it from degenerating into a megalomaniac monster. With this confession, however, Barth also indicated that politics and faith were not two separate matters. Confessing that penultimate things were not the final things was a deed with tremendous political consequences. This was a deed which ought to influence the course of history. Dealing with the functions of the State in an ecclesiastical confessional text meant that politics was not a field about which the church had nothing to say and to which the gospel was not relevant. With this confession, Barth wanted to say that the church and the State should in fact be involved with each other, so that the church could in this way contribute to humanising the reality of life (Brakelmann 1985:14-19).

In the Barmen Declaration, Barth defended not only the distinguishing idea of the two kingdoms, but also the idea of unity. In the 2nd thesis he states the following:

Wie Jesus Christus Gottes Zuspruch der Vergebung aller unserer Sünden ist, so und mit gleichem Ernst ist er auch Gottes kräftiger Anspruch auf unser ganzes Leben...Wir verwerfen the falsche Lehre, als gebe es Bereiche unseres Lebens, in denen wir nicht Jesus Christus, sondern anderen Herren zu eigen wären, Bereiche, in denen wir nicht der Rechtfertigung und Heiligung durch ihn bedürfen.

With this statement Barth paved the way for the development of the later theory of the sovereignty of Christ. To Barth, Christ is the Lord of the world, and therefore He should be obeyed in all areas of life and his rulership over all areas of life should be recognised. In 1935 he based the idea of the emulation of Christ in all areas on the document Evangelium und Gesetz. Against the thesis of the Ansbacher Ratschlag about law and the gospel, he states that the Word of God is the union of law and the gospel. The implication is that the law cannot be known outside the gospel. The will of God can therefore only be read from the revelation of Christ.

According to Barth, historical events and political decisions cannot reveal the will of God. The fact that insight cannot be generally gained into the 
will of God, does not mean that the will of God should not be emulated in all areas of life. According to Barth, the will of God applies to all areas of life, since the church and the world may not be radically separated. In 1938 he based the "sovereignty of Christ" over all areas of life on the document Rechtfertigung und Recht. In these years, Barth was confronted by an unjust State, yet he believed that this State was also under the sovereignty of Christ. Even in its perpetration of injustice it was still being used to do God's will. In spite of being unjust, the State as such ought nevertheless to be maintained. This was why Barth did not regard it as his vocation to strive for less State, but for more State. The State which should ensure law and peace, had to be encouraged to do it better. This is done when the church insists on a democratic constitutional State and when the members of the church take part with the people in elections and exercise their influence on the legislative processes. "Exercise influence" amounted to Barth to exercising the prophetic vocation which the church had received. In short, for Barth (1957:585) the prophetic task of the church amounted to a warning against injustice and the threat of injustice, so that the church could in this way have a beneficial influence on the course of history. The church has this prophetic vocation toward the State, since the church and the State are on the one hand jointly and inextricably subject to Christ's sovereignty. On the other hand the church and the State are jointly the preliminary figures of the eventual and solely true heavenly politeuma. In their differentiation therefore the church and the State remain inextricably bound to each other. Owing to the bond between the church and the State, the church intercedes in prayer for the authorities. The intercession for a tranquil and quiet life is done in the expectation that the church will have the freedom to proclaim the gospel and in this way to exercise a positive influence on society (Jüngel 1986:108-120).

One unanswered question remained for Barth, however, namely what is the nature of the relationship between the church and the State which exist temporarily together under the sovereignty of Christ? In 1946 he answered this question with the slogan "analogy" in the document Christengemeinde und Bürgergemeinde. Barth asserts that the State and the church have a joint vocation concerning a limited number of matters. The State is an institution which has to combat the consequences of sin. In this respect the church may not withhold itself a-politically from the State's struggle, since this task is also the task of the church. In addition, the State may not distance itself areligiously from the church, since the State and the church have the same ultimate vision. Barth believes that the State ought now, with the aid of the church, to strive to resemble the kingdom. Barth also thinks that this ought not to remain an ideal (Gleichnisbedürttigkeit), since the State is also capable of 


\section{The political responsibility of the church}

resemblance (Gleichnisfähigkeit). Resemblances to or analogies of the kingdom arise where the sovereignty of Christ is illuminated by and in politics, and is not concealed. Examples for Barth are instances where the weak and the poor are supported because Christ identified himself with these people; and where secret diplomacy is relinquished because the kingdom is a matter of light, not darkness. The consequence of all this is that to Barth, politics gained a confessional character. Political decisions are displaced in the sphere of the status confessionis. In spite of this, however, Barth never surrendered to a "Christian politics or party". Nor did he ever say that the kingdom could be ethically realised. The fact remains that Barth found it unthinkable that there could be an area of life which could proceed on its own legitimacy without the church having anything to say about it (Jüngel 1986:121-135; De Kruijf 1994:31-38).

Barth's social ethics elicited fierce criticism, particularly from Lutherans but also from Calvinists. The Lutheran Gerhard Ebeling accused Barth of never having been able to understand the deepest intentions of the Lutheran theory of two kingdoms. According to Ebeling, Barth could never understand the radical difference between divine and human justice. For this reason, Ebeling said Barth expected too much of ethics, confused the law and the gospel, and moved from an indefensible political use of the law to an equally indefensible political use of the gospel. In this way Barth reduced theology to a theory of morality. Theology as the discourse of man coram Deo is therefore replaced by a permanent meddling with earthly justice (Ebeling 1962:412; 1982:323-325; Ebeling 1986:66-75). Other Lutherans, such as Gerhard Sauter, also expressed criticism in this vein. Sauter (1973:231-243) also raised the complaint against the Barthians that in theology they were no longer concerned about salvation, but only about justice. As a result of the exaggerated emphasis placed on worldly responsibility, the church became elevated to the bringer of salvation, whereas there was no longer trust in God's management of the world.

Therefore on the Lutheran side (Ebeling 1975:514-520) people maintained that a distinction should be made between salvation and wellbeing, and that the creation of well-being was a matter of reason and not of faith, of expertise and not clerical pedantism (Honecker 1981:135). Sauter (1988:265) insists that the "analogy idea" should be abandoned because dogmatic concepts cannot be made ethically clear. He claims that human justice cannot be used as a means to give insight into divine justice. From the Calvinistic side (De Kruijf 1994:236-246), criticism was expressed particularly about the idea of the prophetic vocation of the church. The lack of Biblical grounding casts suspicion on the whole idea. Barth's idea that the church, in fulfilling its prophetic vocation, could change the course of history, was also 
rightly called into question (Honecker 1982). In spite of the many valid points of criticism made against Barth, it is also true that many points of criticism are exaggerated and completely inaccurate. Therefore it is not surprising that a Lutheran such as Eberhard Jüngel (1986) was consistently prepared to defend Barth. This paragraph, with points for and against Barth, could become extremely long - but this would not make sense. The fact remains: things are not so simple. A choice cannot be made only for the distinction, or for the reciprocal effect of the kingdoms on each other.

Lutheran theologians have exposed themselves to fierce criticism in the past decades. The enormous influence Karl Barth had on the German theological scene compelled the Lutherans to reconsider a number of things. In 1963, the Lutheran World Federation acknowledged during the conference of the Fourth Full Assembly in Helsinki, that the "theory of two kingdoms" as presented and defended in the last decades, was aporetic (Honecker 1981:128-131). After Helsinki ${ }^{8}$ fewer and fewer Lutherans were prepared to work with a theory of two kingdoms in which the two kingdoms are radically separated. In this regard, a brief reference can be made to the case of Martin Seils. Martin Seils (1993:85-106), a theologian from Jena, gave a most insightful perspective on the developments in the German Democratic Republic (GDR) between October 1989 and November 1992. As a convinced Lutheran and a defender for many years of the theory of two kingdoms, he came to realise that the church and the world, faith and politics did indeed concern one another in these years. He, who was accustomed to distinguishing between and keeping apart the kingdom of Christ and the realm of socialism, physically experienced that the Spirit of Christ had led the Lutheran Church in the old GDR to participate in politics. After all the miraculous changes, he could not do otherwise than concede that the sovereignty of Christ also concerned history. Together with the former GDR theologians such as national bishop Noth and Gottfried Forck, Seils (1993:102) speaks of the theory of two kingdoms as the "form within which the Lutheran Church speaks of the sovereignty of Christ." The basic theological motif underlying this shift in theological emphasis is the discovery of the relevance of the trinity theory and the eschatology for the theory of two kingdoms. Seils (1993:102) discovered that the kingdom of the world and the kingdom of Christ are both God's kingdoms, and theoretically therefore they may not be radically separated from each other. Seils (1993:103-104) also discovered that the kingdom had already dawned, and was therefore already present in the old sinful world and was influencing people in their earthly longings.

\footnotetext{
${ }^{8}$ A good example of the discussions which the Lutheran churches held in the old GDR. They fully realised that they could not disregard Barth and his Calvinist tradition. (see Rogge \& Zeddies 1980 for completeness).
} 
In summary: it is hoped that from this excursion it has once again become clear that "Reformatory" theology does indeed want to work with a theory of two kingdoms - but not with a theory of two kingdoms in which the church and the world have nothing to do with each other. The idea that politics and the State are fields about which the church has nothing to say, is not supported in the theological debate after World War II. Therefore we have to tackle anew the difficult challenge of working out a theory for our unique circumstances, one which will enable the Church to fulfil its responsibilities in this particular epoch.

\section{CHALLENGES TO THE CHURCH IN SOUTH AFRICA}

Based on the investigation, it ought to be clear that the relationship between the church and the State cannot be determined and formulated only once and conclusively. This relationship varies and changes in tandem with social and political changes (Honecker 1977:70). For this reason we are at liberty to seek anew a definition of the relationship between the church and the State. In this search, however, we must keep to what is typical of our theological tradition, namely the "Biblical Reformatory Theology". Under "Biblical Reformatory Theology" I wish to understand a combination of the traditional Lutheran and Calvinistic schools of thought. ${ }^{9}$ I trust that the investigation has demonstrated beyond all doubt that the Lutheran and Calvinistic traditions concur that a clear distinction should be made between the two realms, but that these realms may not and should not be radically separated from each other. On this path we should also venture forth within our own unique circumstances.

We should therefore adhere to the theory of two kingdoms, not only because it assists with the ethical orientation process, but also because it is a fundamentally theological matter. We simply have to distinguish between the church and the State ${ }^{10}$, because we are also obliged to distinguish between the law and the gospel, faith and love (Ebeling 1962, Bayer 2003:281-296). We should also adhere to the "theory of the sovereignty of Christ" since Christ is the Lord of the world. Nevertheless one also has to bear in mind the

\footnotetext{
${ }^{9}$ For a long time now I have wrestled with these problematic. In my thesis (Van Wyk 1987) I defended a purely Lutheran position. In the discussion of my thesis, Willie Jonker (1988) admonished me paternalistically to look again at my own Calvinist tradition. This admonition I eventually took seriously (Van Wyk 1995) and began to make a combination of the two traditions. This article is a continuation of this attempt. If success is achieved in this exercise, a contribution will be made to church unity (Staedke 1972:202).

${ }^{10}$ This theological point of departure should be closely adhered to, in spite of the fact that Africa cannot and will not work with these dualisms. Theologians of Africa work with a holism in which no distinctions are made between heaven and earth, the living and the dead, the present and the future (cf e g Bediako 1997).
} 
"hermeneutic difference" (Gestrich 1986) between the Reformers and the contemporary political constellation. ${ }^{11}$ We shall have to realise that the Reformers' theology cannot be taken over in all respects without causing problems. Careful consideration will have to be given to (a) the implications of "democratic constitutionality", (b) the confusion that a pluralistic society creates, and (c) the uncertainty which "Africanisation" holds for the church and theology.

\subsection{Democratic constitutionality}

Against the background of the European ecclesiastical experience it can be assumed that the ethical pronouncements of the church will become more and more controversial in future and will find less and less concurrence in the church and among the public. One of the reasons for this is that the members of the church simply do not reveal any comprehension of the "Reformatory" pattern of thought and world-view, since they are people who orient their lives within the modern processes of life. "Reformatory" thinking asks what God's will is for life. In a democracy people do not (always) ask what God's will is, but rather what the will of the majority is. They do not seek for an authoritative opinion outside the negotiation processes, but for consensus within these processes. The politicians of a democratic constitution are not interested in the authoritarian guidance of the church, but seek the minimum consensus in society (De Kruijf 1994:9-12). The days are also long gone when the members of the church and the citizens of the country could be regarded and treated as submissive subjects only. Today everyone takes part in the decision-making processes. People regard themselves as having reached full majority and adulthood, and do not wait for the church to act on their behalf (Joest 1986:608). The church will simply have to adapt to these new circumstances.

The church may not ever abandon the search for God's will in all fields of life. The will of God does not apply only to church people of firm belief. The will of God is a good will which can only and will only be to the benefit of the entire community, and that is why the church has the responsibility for making God's will known to the public. The question is now: how can the church keep to the will of God and how can the church promote the will of God in a democratically oriented society? In my opinion, the Leyden ethicist G G de Kruijf offers a useful pointer which is also practical in our unique circumstances. His view (1994:13-20) is that we should follow a double thinking process: (1) thinking from one's own presupposition about faith and

\footnotetext{
${ }^{11}$ In Middle Europe the realisation has been growing in recent decades that one can no longer without problems use "Reformatory" ethics for our century (Staedke 1972:214). The most meritorious contribution in this regard comes from the German theologian Trutz Rendtorff (cf Wendebourg 1992 for an overview).
} 


\section{The political responsibility of the church}

(2) thinking which strives for a minimum of consensus within the State. In this way, thinking is based on principles, the historical realities are taken into account, and the political relevance of Christian ethics is sought. ${ }^{12}$

The church seeks the emulation Jesus Christ in all fields of life, but offers no Christian morale as a code which should be applied causally. This route makes the church "sober" and "watchful". Sober means: the church remains rational. It follows valid reasoning. It accepts the influences from the environment. Vigilance means: the church remains sensitive to the boundaries. It keeps to matters, which really concern it. In this way the church can separate itself from the world, but it can also keep on seeking consensus with others. The implication is that the church does not need to point out the relevance of the gospel by feverishly searching for social-ethical translations of Christian insights, but only needs to ensure that fellowship with Jesus finds outward form in the world. Christian life in the "new South Africa" will therefore amount to a life of alienage. The church will therefore form a subculture, but a subculture of a large cultural community. This entails that Christian ethics should be involved in the entire culture - but only from the perspective of the congregation's interests. For this reason the question will be asked: How do we live before the countenance of God? But not: How can we enrich the culture with insights showing the relevance and attractiveness of the Christian faith? This does not mean, however, that Christian ethics will degenerate into esotericism, because the church will still continue to seek an argumentative debate in the whole of society so that it can prevent ethics from becoming decisionist and therefore totalitarian in its gist (De Kruijf 1994:19). This means that the church will orient itself to the "Reformatory" theory of two kingdoms, but will guard against withdrawing itself from the realities. The church will have to emulate Christ in all fields of society, but have to accept philosophically the limits of its influence.

The approach to the Lutheran theory of two kingdoms should not prevent us from pursuing the truth of our own Calvinist tradition. This tradition (cf Rohls 1987:301-313 for a concise overview) amounts, in short, to not making a radical separation between the church and the State. In some or other way we shall still have to make an attempt for the church to influence the authorities. It would be unwise to argue like a Richard Rothe (Drehsen 1994) that the ecclesiastic period is regrettably over, and that we now have to hope for the morality of judges and politicians. A Calvinistic church in changed circumstances will still have to influence the legislative processes, by making the will of God known to influential people. This influence will always amount

\footnotetext{
${ }^{12}$ De Kruijf distances himself (and I share his distance) from this point by Herman Kuitert (1986) who defends the autonomy of morality.
} 
to attempts by the church to persuade opinion makers and legislators of the church's opinion by means of convincing arguments. The church may never use coercion to force its opinions on the authorities, since the church's confessional task always has to occur non vi, sed verbo (Joest 1986:609).

What people ask for and seek is not the kingdom on earth, but for what least contradicts the kingdom - because we do after all know that whoever wants to create heaven on earth will in the end create hell (Breit 1983:317). In consequence of this conviction, we proceed from the standpoint that Christ can and must be emulated in all fields of life - or as Wilfried Joest (1986:611) puts it:

Es kann jedenfalls nicht heißen: In der Gesinnung der Christian die Brüderlichkeit - in der Politik und Wirtschaft der Machtkampf, in dem the Stärkeren sich rücksichtlos durchsetzen. Vielmehr: In der Gemeinde Christi die Bruderschaft - im Staat the Gerechtigkeit, die sich gerade um das Recht der Schwachen kümmert. Nicht: In der Innerlichkeit der Christian die Vergebungsbereitschaft nach dem Gebot der Bergpredigt, in der Politik das Gesetz von Schlag und Gegenschlag. Vielmehr: In uns the Bereitschaft zu vergeben - in den innerstaatlichen wie internationalen Konflikten die Bereitschaft, miteinander zu reden und Wege der Verständigung zu suchen.

With such a standpoint, one bears witness to a confession that God can move people extra muros ecclesiae to do His will, and one rejects Honecker's (1981:136-139) standpoint that social-ethics have nothing to do with the will of God. If the opinion is that attempts in this regard are in any case an exercise in futility, all that is required is a reminder of the consequences of such a standpoint. Wolfhart Pannenberg (1981) points out as a Lutheran that the radical separation of religion and politics in Germany led not only to the phenomenon of "secularisation", but also to the phenomenon of "senselessness". In the end, people will not tolerate having religion restricted to the private sphere, and having social life relinquished to the tyranny of rationality.

People simply cannot find their way ethically when ethics are dissociated from religion (Kant). When this is done, people search for meaning in their lives in all kinds of subcultures and sects, or those who are not in favour of doing this may find refuge in some or other ideology. Certainly the solution does not lie in pursuing a totalitarian theocracy, but in making an ecumenical attempt to keep the gospel alive in all democratic discussion forums and to concentrate the preaching of the law on setting democratic goals (Breit 1983:319). Preaching the law will therefore have to be actualised so that it can be relevant and useful for members where they have to defend 


\section{The political responsibility of the church}

and proclaim the truth of the Word of God in democratic discussions. Bearing witness against the authorities has not for a long time been the sole responsibility of the General Synod or its Commission. It is also the responsibility of presbyterian meetings, church councils and all members. The great responsibility which ecclesiastical guidance has at the present juncture in our history is to bring every member and office-bearer to the realisation that in a democracy, they are responsible for the gospel. However, there would have to be continuous admonitions that political arguments should never be presented as ecclesiastical arguments. Just as there should be warnings against a religious self-misunderstanding, there should also be continuous warnings against a political self-misunderstanding of the church (Jüngel 1984:45, 60).

\subsection{Plurality in society}

South Africa is a multi-religion, multi-confessional country. These realities are acknowledged in the new political dispensation. One religion and one confession can no longer insist on being given preference by the State. For this reason the State, and by implication the authorities, have a neutral stance toward religion and the church. In our pluralistic society the authorities can no longer be expected to transform into legislation the likes and dislikes of a particular religion. The days are long gone when the authorities were seen as the extension of a particular confessional group. The realities of South Africa compel us to go out from a theory of two kingdoms. We do not even have to demand it theologically. However, the implication is not that the church should withdraw from society. As a "Reformatory" church may not renounce its identity, it will have to continue in less favourable circumstances to bear witness against the authorities. Even if the Christian religion is no longer in favour and even if the Calvinist churches no longer have preference, it remains the church's responsibility to inform the authorities about the will of God (this we can learn positively from Pannenberg 2004b and Jüngel 2000). It is clear, however, that the Hervormde Church will have to change its attitude to ecumenical co-operation. People have to realise that churches can no longer individually persuade the authorities to accept particular insights and standpoints. On certain matters there will have to be common witnessing and if it is possible and desirable, also joint witnessing.

South Africa is also a country with a multiplicity of cultures. This multiplicity is continually increasing. Monocultural groups are changing into multicultural groups. This phenomenon applies equally to the Afrikaner. The cultural unison and uniformity prevailing just a few decades ago, has already disappeared to a large extent. This has far-reaching consequences for the 
Nederduitsch Hervormde Church, which is closely associated with the Afrikaner culture. The Church will in future have to be very cautious about taking a standpoint on culturally related issues, such as education matters. Under no circumstances may it proceed any longer from the assumption that the members of the Church have a common cultural vision. Therefore great care will have to be taken not to alienate loyal members from the Church through decisions in the cultural field, which are intended to bind and coerce their consciences (Belgic Conf art 32). Whoever wants to deny and disregard this cultural plurality would do immense harm to the Church.

There are a multiplicity of political and ideological convictions inside the country, Afrikanerdom and the Church. The Church could save itself a great deal of misery by taking note of these realities. Under no circumstances may the Church be blind to the political pluralism in its own ranks. Biased political benevolence might polarise the members of the Church to an unacceptable level.

\section{3 "Africanising"}

South Africa is undergoing a transformation process, called "Africanising". At this stage, no one can say with certainty what "Africanising" will eventually hold for us. The following, which have already happened, require theological comment:

- The traditional "Calvinistic" relationship between the church and the State has vanished. The Church is being deliberately ignored as a public and political opinion former. Media such as the SABC deliberately sideline the Church in matters of public interest. The authorities deem the witnesses of the Church as of no real importance in the legislative processes, and for this reason the Church's witnesses are merely ignored. This could easily provoke the reaction that the Church should withdraw from public life. In my opinion, however, the Church has to remain true to its theological tradition, especially in this alien and perhaps even hostile environment. Precisely in these circumstances the Church may not stop defending and conveying the truths of the "Reformatory" tradition. Even if organs of State and certain media try to limit and even negate the Church's influence, the Church should not withdraw from public life. The opportunities for bearing witness should be seized at all costs. Nor should the Church withdraw too quickly from opportunities such as chaplain services and other public service matters and in this way assist the neutrality of the State 
(Slenczka 1987:1078). Everything possible should also be done to increase these opportunities.

- The possibility that the "Africanising process" may push the Calvinistic churches and perhaps even the Christian religion out of the political decision-making sphere, raises the spectre that the State and politics may gain the eventual function of givers of meaning. In particular, the Church has the vocation to warn and protect all people against this danger. The Church has the responsibility for bearing witness to the kingdom of God. Together with the Barmen Declaration the Church must indicate where the boundaries of the State are. Members of the Church and citizens of the country may not be surrendered to the ideology that may make the State and politics the last meaning-giving power. Gerhard Ebeling (1962:408) was right when he said that the theory of two kingdoms is essential for salvation, since it brings clarity in obscure situations. The light it may bring us in our unique situation is the realisation that one cannot expect full self-actualisation from the State (Wendebourg 1992:200). The renewed realisation that a political constellation may not be confused with the kingdom of God could free certain people from the heartache of the "lost-and-gone kingdom" which would have accompanied the change in power in South Africa, and release others from the excitement about the "newly dawned kingdom" that would have coincided with the new political dispensation. We ought to develop an understanding in this country for the concept of the State, formulated by people such as Busch who learned from bitter experience that it is fatal to expect too much from the State. We ought today to say with him (1992:176): "Der Staat bedarf einer Begrenzung, damit er nicht zur Heilsanstalt, zum Götzen und so zum totalen Staat wird. Und wenn er ein rechter Staat ist, bejaht er seine Begrenzung. Und indem er so sich selbst begrenzt, läßt er Raum, den freien Raum, den the Kirche braucht, um ihrer eigenen Aufgabe nachzugehen." The distinctive element in the theory of two kingdoms is intended to set limits to the idea that politics is the all-destined power (Schütte 1978:352). The realm of the world will not pass theologically into the realm of God. The realm of the world is indeed a creation of God which is not excluded from the sovereignty of God, but it is not the kingdom of God. The realm of the world concerns God's will to maintain and order it, but not His will to redeem it. For this reason the authorities will have to be taught that they have a responsibility to concede that through the 
Church they can and should be called to account (Jüngel 1984:44). This perspective may not be perverted again. The fact that it is said that the State is not divine does not mean that the State is a devil (Jüngel 1984:52). The right to criticise the authorities does not mean that they can be placed in the sphere of evil. The church in the new South Africa may not therefore engage solely in negative criticism, but should also make a positive contribution to the development of law (Pannenberg 1978:323-342) in the country. All that the church could eventually offer with a persistently negative attitude would be a platform for extra-parliamentary groups which would use the church for their own selfish purposes (Slenczka 1987:1080).

- "Africanising" has already had the result that group thinking and group action have had a strong effect on the course of public affairs. Individual and principled thinking are becoming increasingly minimalised in big and important decisions. The result of the "populist democracy" driving out the "liberal democracy" is that group pressure and mass action has become the yardstick of truth and desirability. The pursuit of collective-action goals is becoming the main interest in politics. The Church will have to fight the temptation to take part in the pursuit of collective action goals. The Church may not be directed primarily to the pursuit of social ideals, since the Church's main interest is its position coram Deo (Sauter 1978:122). If the Church were to do this, it would safeguard itself from a "political theology" which would allow no room for the basic truths of the theory of two kingdoms.

- The driving out of individual thought has also had the result that individual cultures have become overwhelmed by the wave of egalitarian thought. Cultural traditions which have been strongly influenced by "Reformatory" thought are therefore encountering strong opposition and even hostility from groups which are to a large extent influenced by the motives of the traditional religions of Africa. The Church will simply have to learn to protect its identity and fulfil its vocation in a hostile world. Resistance and opposition may not make the Church relinquish its consistent emulation of Christ and the proclamation of its message in Africa. 


\section{Works consulted}

Barth, K 1935. Evangelium und Gesetz. München: Kaiser.

Barth, K 1938. Rechtfertigung und Recht. Zürich: Zollikon.

Barth, K 1946. Christengemeinde und Bürgergemeinde. Zürich: Zollikon.

Barth, K 1957. Kirchliche Dogmatik. Band III, 4. Zürich: Zollikon.

Bayer, O 2003. Martin Luthers Theologie: Eine Vergegenwärtigung. Tübingen: Mohr.

Bediako, K [1995] 1997. Christianity in Africa: The renewal of a non-western religion. New York: Orbis Books.

Boshoff, P B 1995. Die kerk van die Woord. HTS 51, 581-594.

Botha, S J (red) 1989. Belydende volkskerk. Pretoria: KITAL.

Buitendag, J 1990. Die paradigmas van "Kerk en wêreld 2000". HTS 46, 690707.

Brakelmann, G 1985. Barmen V - ein historisch-kritischer Rückblick. EvTh 45, 3-20.

Breit, H 1983. Politik in der Predigt - politische Predigt? KuD 29, 306-322.

Busch, E 1992. "Gott hat nicht auf sein Recht verzichtet": Die Erneuerung der Kirche im Verhältnis zum politischen Bereich nach dem Verständnis der reformiertenReformatoren. EvTh 52, 160-176.

Calvyn, J [1559] 1992. Institusie van die Christelike Godsdiens, Boek 4. Potchefstroom: CJBF.

De Kruijf, G G 1994. Waakzaam en nuchter: Over christelijke ethiek in eendemocratie. Baarn: Ten Have.

Drehsen, V 1994. Vision eines kirchenfreien, ethischen Zeitalters des modernen Christentums: Richard Rothe (1799-1867). BthZ11, 201218.

Duchrow, U 1977. Typen des Gebrauchs und Missbrauchs einer Lehre von zwei Reichen und zwei Regimenten, in Zwei Reiche und Regimente: Ideologie oder evangelischeOrienterung, 273-304. Gütersloh: Mohn. (SEE 13.)

Ebeling, G 1962. Die Notwendigkeit der Lehre von den zwei Reichen, in Wort und Glaube, Band I, 407-428. Tübingen: Mohr.

Ebeling, G 1972. Leitsätze zur Zweireichelehre. ZThK 69, 331-349.

Ebeling, G 1975. Wort und Glaube. Band III. Tübingen: Mohr.

Ebeling, G 1982. Usus politicus legis - usus politicus evangelii. ZThK 79, 323348.

Ebeling, G 1986. Über die Reformation hinaus? Zur Luther-Kritik Karl Barths. ZThK Beiheft 6. Zur Theologie Karl Barths, 33-75.

Gestrich, C 1986. Die hermeneutische Differenz zwischen Barth und Lutherangesichts der neuzeitlichen Situation. ZThK Beiheft 6. Zur Theologie Karl Barths, 136-157.

Geyer, C-F 1994. Einführung in die Philosophie der Kultur. Darmstadt: Wissenschaftliche Buchgesellschaft. 
Goold, G (ed) 1976. The epistle to Diognetus, in The Apostolic Fathers, II. London: Harvard University Press. (The Loeb Classical Library.)

Graf, F W 1990. Königsherrschaft Christi in der Demokratie: Karl Barth und die Deutsche Nachkriegspolitik. EvKomm 23, 735-738.

Gregersen, $\mathrm{N}$ e a (ed) 2005. The gift of grace: The future of Lutheran theology. Minneapolis, MN: Fortress Press.

Greive, W 1987. "Zweireichelehre" als Königsherrschaft Jesu Christi. KuD 33,102-119.

Henriksen, J-O 2005. Pluralism and identity: The two-kingdoms doctrine challenged by secularization and privatization, in Gregersen, $\mathrm{N}$ e a (ed) 2005. The gift of grace: The future of Lutheran theology. 277-290. Minneapolis, MN: Fortress Press.

Herrmann, C 2004. Politische Ethik der Buße: Christliche Politik und Zweireichelehre am Beispiel von Veit Ludwig von Seckendorff mit einem Ausblick auf die neuere Diskussion. NZSTh 46, 226-263.

Honecker, M 1977. Hilfe zur Entschlüsselung: Welchen Sinn hat heute die Zweireichelehre? LM 16, 70-74.

Honecker, M 1981. Thesen zur Aporie der Zweireichelehre. ZThK 78, 128140.

Honecker, M 1982. Prophetie im Widerspruch zur Ethik: Geschichtsdeutung ist immer mehrdeutig. EvKomm 15, 65-67.

Honecker, M 1990. Einführung in die Theologische Ethik. Berlin: De Gruyter.

Joest, W 1986. Dogmatik. Bd. 2: Der Weg Gottes mit dem Menschen. Göttingen: Vandenhoeck. (UTB 1413.)

Jonker, W 1988. Proefskrifbespreking van I W C van Wyk - Das Theodizeeproblem als Orientierungspunkt der kirchenpolitischen und theologischen Streitfragen. HTS 44, 935-938.

Jüngel, E 1984. Mit Frieden Staat zu machen: Politische Existenz nach Barmen, V. München: Kaiser. (Kaiser Traktate 84.)

Jüngel, E 1986. Zum Verhältnis von Kirche und Staat nach Karl Barth. ZThK. Beiheft 6. Zur Theologie Karl Barths. Beiträge aus Anlaß seines 100. Geburtstages, 76-135.

Jüngel, E 2000. Kirche und Staat in der pluralistischen Gesellschaft, in Indikative der Gnade - Imperative der Freiheit. Theologische Erörterungen, IV, 296-311. Tübingen: Mohr.

Kern, U 1986. Die durch Barmen definierte Zweireichelehre. ThZ 42, 237-254. Kuitert, $\mathrm{H}$ 1986. Alles is politiek maar politiek is niet alles: een theologischperspectief op geloof en politiek. 3e Druk. Baarn: Ten Have.

Küng, H 1994. Das Christentum: Wesen und Geschichte. München: Piper.

Lohse, B [1981] 1983. Martin Luther: Eine Einführung in sein Leben und sein Werk. 2 Aufl. München: Beck.

Luther, M 1883. vv WA = Weimarer Ausgabe 
Luther, M [1518] 1991a. Sermon über die zweifache Gerechtigkeit, in Die Werke Luthers in Auswahl, Bd 1. Hrsg v Aland, K, 368-378. (= WA 2, 145-152) Göttingen: Vandenhoeck. (UTB1656.)

Luther, M [1520] 1991b. An den christlichen Adel deutscher Nation von des christlichen Standes Besserung, in Die Werke Luthers in Auswahl, Bd 2. Hrsg v Aland, K, 157-170. (= WA 6,405-415. Göttingen: Vandenhoeck. (UTB1656.)

Luther, M [1523] 1991c. Von weltlicher Obrigkeit, wie weit man ihr Gehorsam schuldig sei, in Die Werke Luthers in Auswahl, Bd 7. Hrsg v Aland K. 951. (= WA II,246-280). Göttingen: Vandenhoeck. (UTB 1656.)

Luther, M [1526] 1991d. Ob Kriegsleute auch in seligem Stande sein können, in Die Werke Luthers in Auswahl, Bd 7, 52-86. (= WA 19,623-662).

Luther, M [1529] 1991e. Vom Kriege wider die Türken, in Die Werke Luthers im Auswahl, Bd 7, 94-118. (= WA 30,2,107-148).

Moltmann, J 1984. Politische Theologie - Politische Ethik. München: Kaiser.

Nederduitsch Hervormde Kerk van Afrika. 1985. Kerk en wêreld 2000. Pretoria: KITAL.

Nowak, K 1981. Zweireichelehre: Anmerkungen zum Entstehungsproze $B$ eiener umstrittenen Begriffsprägung und kontroversen Lehre. ZThK 78, 105-127.

Pannenberg, W 1978. Christliche Rechtsbegründung, in Handbuch der Christlichen Ethik, Band 2, 323-342. Hrsg v Hertz, A u a Freiburg: Herder.

Pannenberg, W 1981. Die theokratische Alternative, in Fortschritt ohne Maß?, 235-251. Hrsg v Löw, R u a. München: Piper.

Pannenberg, W 2004a. Christlicher Glaube und Gesellschaft, in Beiträge zur Ethik, 9-22. Göttingen: Vandenhoeck.

Pannenberg, W 2004b. Christliche Rechtsüberzeugungen im Kontext einer pluralistichen Gesellschaft, in Beiträge zur Ethik, 55-68. Göttingen: Vandenhoeck.

Pawlas, A 1990. Evangelische politische Theologie. Zwei-Reiche-Lehre und Lehre von der Königsherrschaft Christi als ihre Kriterien und Interpretamente. KuD 36, 313-332.

Pont, A 1969. Kerk en volk. HTS 25, 202-218.

Pont, A 1991. Die verhouding "kerk en volk" in die jare 1835-1900 in die Oorvaalse: 'n Terreinverkenning. HTS 47, 783-799.

Reuter, H-R 1983. Kunst der Differenzierung: Über Schaden und Nutzen der Zwei-Reiche-Lehre. DtPfrBI 83, 171-173.

Rogge, J \& Zeddies, H (Hrsg) 1980. Kirchengemeinschaft und politische Ethik: Ergebnis eines theologischen Gesprächs zum Verhältnis von Zwei-Reiche-Lehre und Lehre von der Königsherrschaft Christi. Berlin: Ev Verlagsanstalt.

Rohls, J 1987. Theologie reformierter Bekenntnisschriften. Göttingen: Vandenhoeck. (UTB1453.) 
Ruokanen, M 1988. Augustin und Luther über die Theologie der Politik. KuD 34, 22-41.

Sauter, G 1973. Heilsvorstellungen und Heilserwartungen: Notizen zurtheologischen Orientierung. EvTh 33, 227-310.

Sauter, G 1978. Chancen theologischer Verständigung, in Was ist los mit der Deutschen Theologie? Antworten auf eine Anfrage, 109-122. Hrsg v Janowski, N und Stammler, E. Stuttgart: Kreuz.

Sauter, G 1988. Eschatologische Rationalität, in In der Freiheit des Geistes: Theologische Studien, 166-197. Göttingen: Vandenhoeck.

Schrey, $\mathrm{H}-\mathrm{H}(\mathrm{Hg})$ 1969. Reich Gottes und Welt: Die Lehre Luthers von den zwei Reichen. Darmstadt: Wiss. Buchgesellschaft.

Schütte, H-W 1978. Zwei-Reiche-Lehre und Königsherrschaft Christi, in Handbuch der Christlichen Ethik, Band 1, 339-353. Hrsg v Hertz, A u a. Freiburg: Herder.

Schwarzwäller, K 1980. Theologische Kriterien für politische Entscheidungen bei Luther. KuD 26, 88-107.

Seils, M 1993. Zweireichelehre in der Wende: Erfahrungen und Gedanken aus der ehemaligen DDR. NZSTh 35, 85-106.

Slenczka, R 1987. Kirche und Politik: Ein ekklesiologischer Abriß, in Weisheit Gottes - Weisheit der Welt. Band II. Festschrift für Joseph Ratzinger zum 60. Geburtstag, 1073-1086. Hrsg v Baier, W und Horn, S e a. Erzabtei St. Ottilien: EOS Verlag.

Smith, D J 1988. Die verhouding tussen kerk en staat: Enkele modelle met verwysing na die reg van opstand teen die staat. HTS 44, 434-449.

Staedtke, J 1972. Die Lehre von der Königherrschaft Christi und den zwei Reichen bei Calvin. KuD 18, 202-214.

Storm, J M G 1989. Die Voortrekkerkerk: 1836-1853. Pretoria: KITAL.

Tödt, H E 1980. Die Bedeutung von Luthers Reiche- und Regimentenlehre für heutige Theologie und Ethik, in Gottes Wirken in seiner Welt: Zur Diskussion um die Zweireichelehre, Band II, 52-126. Hrsg v Hasselmann, N. Hamburg: Uitgewer onbekend.

Van Wyk, I W C 1978. Das Theodizeeproblem als Orientierungspunkt der kirchenpolitischen und theologischen Streitfragen: Eine Auseinandersetzung mit Jürgen Moltmann. DD-proefskrif, Universiteit van Pretoria.

Van Wyk, I W C 1991. Protesoptogte en die rol van die Nederduitsch Hervormde Kerk. HTS 47, 716-745.

Van Wyk, I W C 1994. Nog geslote eredienste? Deel 1. HTS 50, 755-779.

Van Wyk, I W C 1995. Verset en rewolusie. HTS 51, 487-516.

Van Wyk, I W C 1996. Etiek in die "nuwe Suid-Afrika". HTS 52, 165-178.

Villa Vicencio 1986. Between Christ and Caesar: Classic and contemporary texts on church and State. Cape Town: David Philip.

Walther, Chr 1990. s v Königherrschaft Christi. TRE. 
Wendebourg, E-W 1992. Die Reformulierung der lutherischen ZweireicheLehre in T Rendtorffs Ethik. KuD 38, 199-229.

Wenz, G 1995. Sine vi, sed verbo? KuD 41, 136-157.

Westhelle, V 2005. The Word and the mask: Revisiting the two-kingdoms doctrine, in Gregersen, $\mathrm{N}$ et al (eds). The gift of grace: The future of Lutheran theology, 167-178. Minneapolis, MN: Fortress Press.

Zimmerman, G 1987. Die politische Bedeutung der Zwei-Reiche-Lehre. ZEE $31,392-410$.

Zimmerman, G 1993. Gottesbund und Zwei-Reiche-Lehre bei Calvin und in den "Vindiciae contra tyrannos". ZKG 104, 28-48.

Zwingli, U [1523] 1981. Von göttlicher und menschlicher Gerechtigkeit, in Sämtliche Werke, Band II: Corpus Reformatorum Band, 89. Hrsg v Egli, E und Finsler, G. München: Kraus Reprint. 